\title{
機械学習を用いた電気めっきのプロセスパラメータの決定
}

\author{
廣瀬 伸吾 ${ }^{\mathrm{a}}$, 荒川さと子 ${ }^{\mathrm{b}}$, 江塚 幸敏 ${ }^{\mathrm{b}}$ \\ ${ }^{\mathrm{a}}$ (国研) 産業技術総合研究所エレクトロニクス・製造領域 研究戦略部 ( ⿳ 一 305-8560 茨城県つくば市梅園 1-1-1) \\ b (国研) 産業技術総合研究所 製造技術研究部門 ( T 305-8564 荻城県つくば市並木 1-2-1)
}

\section{Decision Software of Recommended Condition Parameters of Electro-plating Using Machine Learning Technique}

\begin{abstract}
Shingo HIROSE ${ }^{\text {a }}$, Satoko ARAKAWA ${ }^{\text {b }}$ and Yukitoshi EZUKA ${ }^{\text {b }}$
${ }^{a}$ Department of Electronics and Manufacturing, National Institute of Advanced Industrial Science and Technology (AIST)(Tsukuba Headquarters, 1-1-1 Umezono, Tsukuba, Ibaraki 305-8560)

${ }^{\mathrm{b}}$ Advanced Manufacturing Research Institute, National Institute of Advanced Industrial Science and Technology (AIST)(1-2-1 Namiki, Tsukuba, Ibaraki 305-8564)
\end{abstract}

Keywords : Machine Learning, Electro-plating, Database, Data Analytics, Expert Skill

\section{1. はじめに}

近年のコンピュータの計算能力や通信技術に関わるハード ウェアの進展により, 一昔前では想像できなかった多量の デー夕を取り扱う環境が整いつつある。また, 人工知能 $(\mathrm{AI})$ 開発によく使われるソフトウェアライブラリが充実してきて おり, 多量のデー夕に数学的処理を施して有益なものにする デー夕解析技術の進展も目覚ましい。こうした背景には, ラ イブラリを有効利用するだけで AI のアプリケーション開発 を実践することが可能であり，技術を活用する上での参入障 壁が低くなったことも大きい。機械学習のような計算機能力 が大きくなればなるほど威力が増す手法は, 今だから可能と なった解析技術として, 多くの取り組みがなされてきている。

また一方で, 日本の製造業では, 少子高齢化が大きな問題 として挙がっている。2025 年問題とも言われており, 15 歳 ～64 歳の生産年齢人口が 7,000 万人まで落ち込み, 国民の 3 人に 1 人が 65 歳以上, 5 人に 1 人が 75 歳以上になると言わ れている。これにより,「労働力の低下」や「働き手不足」 が深刻な問題となる。機械学習などのデー夕解析技術や IT 技術を積極的に活用していくことは，こうした働き手不足を 補う意味でも，ますます重要になってくるといえる。

筆者らは,「めっき技能のデジタル化」をテーマにして, 長年研究開発に取り組んできた。本稿では, MT（製造技術） と IT (情報技術)の融合化を図る取り組みの一つとして ${ }^{1), 2)}$, めっき技術のデータベース化や，めっきプロセスパラメータ と膜特性との相関関係のデジタル化, めっきプロセスパラ メー夕決定の際における機械学習の適用について述べる。
2. めっきプロセスのデジタル化・データ化 と機械学習の適用

\section{1 めっきデータベース}

湿式めっきプロセスでは，素地にめっきを施すことにより 堆積膜を得るが, 製品となるデバイスや部材の表面を硬くし たり, 腐食に強くしたり, 導電性を付与させるなど, 様々な 機能を素地に付与させることができる。その際に, どのよう な種類のめっき材料を使い, どのような膜特性を実現させる のかは, 実験評価で加工レシピを手に入れるか, 文献等を詳 細に調べることが必要である。そこで筆者らは, 加工レシピ のデジタル化に着目し, めっきで実現する機能ごとに, めっ き事例デー夕を整理し, めっき条件と膜特性との相関デー夕 を提示可能とする「めっきデータベース」を構築した ${ }^{3), 4)}$ 。

図 1 には, WEB 画面上に，ユーザがめっきで得られる機 能 (機械特性, 防食特性, 構造特性, 電気特性, めっき浴特 性など)から一つの機能を選択し, 次に表示される画面にお いて, 各種の膜特性をプルダウンメニューから選択する。例 えば, 膜機能を「機械特性」とするとメニューでは, 硬さ, 内部応力, 引張強度, 伸び率, 摩擦係数などの機械特性の中 から一つを選択することとなる。次に，めっき材料( $\mathrm{Ni}$ およ びその合金, $\mathrm{Cu}$ およびその合金, $\mathrm{Au}$ およびその合金, など） から一つの「めつき材料」を選択して決定ボタンを押すと, 検索により事例データが表示される。その中から事例を一つ 選択することで, めっき条件・めっき事例データが閲覧でき る。めっきデータベースを利用することで, ユーザが必要と するめっき膜を得るためのプロセス知見を素早く得ることが できる。

なお，利用希望者は加工技術データベース・ウェブサイト (URL : http://http://www.monozukuri.org/db-dmrc/index.html) に アクセスし，利用申し込み手順にそって ID とパスワードを 


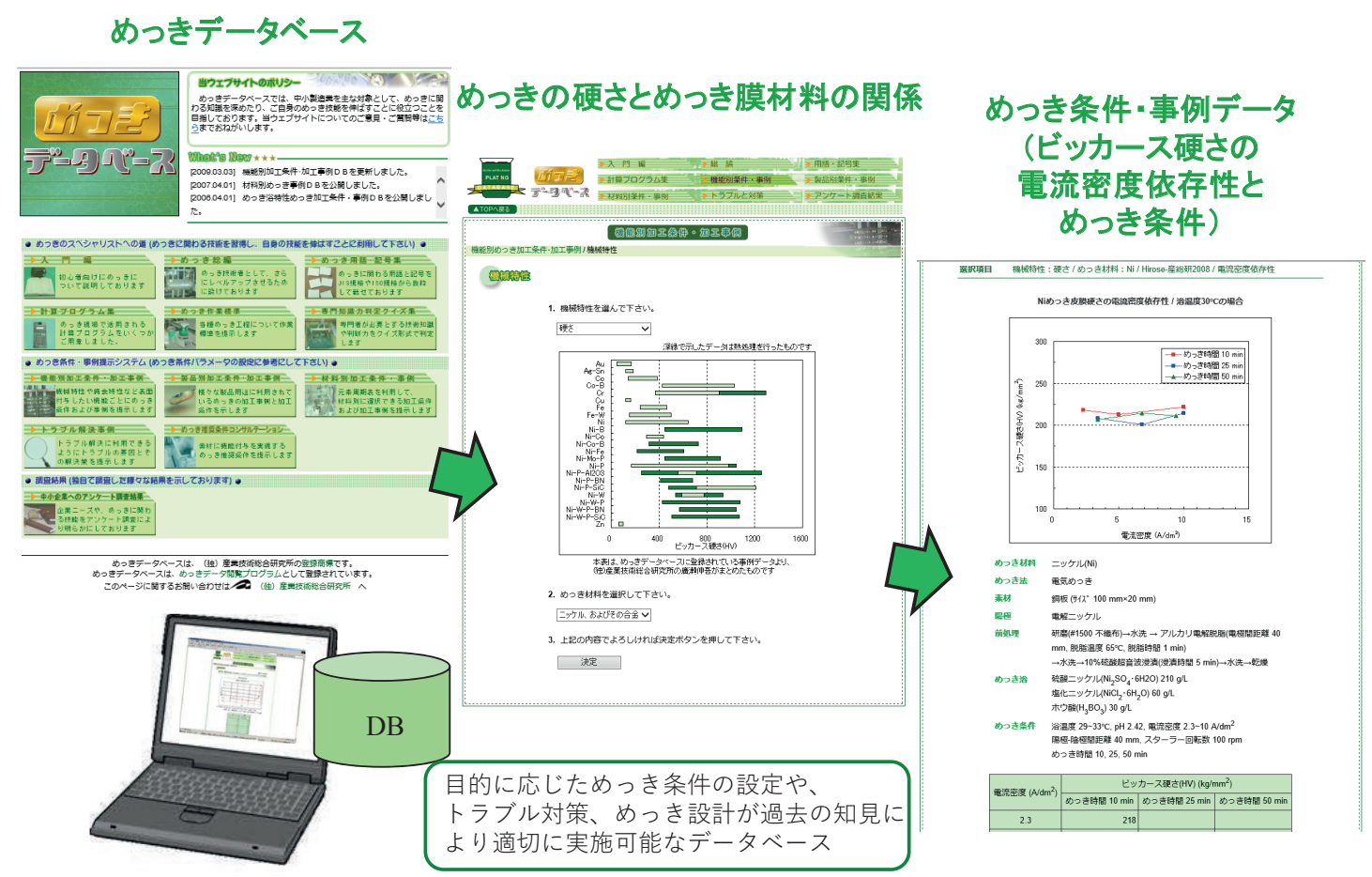

図 1 めっきデータベース(機能別めっき加工条件・事例データの表示の流れ)

受け取ることにより, 複数の加工技術のデータベースを「めっ きデータベース」とともに閲覧利用できる(利用に関しては 現在無償)。

筆者が独自に行っためっき中小受託加工企業者へのアン ケート調査によると, もっとも優れた熟練者の有する技能の 一つとして, 「適切なめっき条件(浴組成, $\mathrm{pH}$, 浴温度, めっ き時間など)の設定ができる」という回答が得られている ${ }^{5), 6)}$ 。 「めっきデータベース」は, 利用者が必要とする膜機能, 膜 特性, 加工条件等, 手軽にめっき加工レシピが得られ，めっ き設計を素早く実現できることが利点となる。今後, デー夕 ベースの加工事例データが増すにつれて, より多様な要求に 応えられるようになれば，いずれは，高度の熟練者だけが提 供できためっきの知識や加工ノウハウを機械が教えてくれる ようになるかもしれない。こうしためっきの知識技能の IT 化は, 知識技能やノウハウを次の世代へ円滑に継承すること にも有効であると考えている。

\section{2 めっき条件と膜特性の相関関係のデジタル化}

めっき技能者検定 1 級の学科試験問題では, 「標準クロム めっき浴(サージェント浴) を使用して, 温度 $60{ }^{\circ} \mathrm{C}$, 電流密 度 $15 \mathrm{~A} / \mathrm{dm}^{2}$ ，でめっきすると, 乳白色のクロムめっきができ る」という問題に対して○×で回答しなければならない ${ }^{7)}$ 。 クロムサージェント浴を用いた硬質クロムめっきでは, ビッ カース硬さが 1000 以上の硬さの範囲で, 光沢を有している 領域と微小クラックが表面に入っている領域と条件的に重な る領域がある。これらの条件範囲は，おおむね温度 35 $65{ }^{\circ} \mathrm{C}$, 電流密度 $20 \sim 80 \mathrm{~A} / \mathrm{dm}^{2}$ の範囲であり, 三日月状に分 布している。この問題では, 乳白色の領域を指定しているが, これはいわゆる久陷領域であり，実用上から外れた条件領域 である。このことは, 高度のめっき技能者は, 正常なめっき 条件だけでなく, 正常から外れためっき条件についても膜と
してどのような結果となるのかを知っておくことが必要であ るということが示唆される。すなわち, 高度めっき熟練者は, めっき条件パラメータと皮膜特性との因果関係を頭の中に知 識として蓄積しており, 必要に応じて適切にめっき条件を提 示して実行できる人物であるといえる。

筆者がデー夕整理体系化を進めていく中で，めっきで得ら れる膜は同時に複数の機能を満たすケースも多いことが再確 認できた。例えば，光沢・意匠性を持ちながら腐食に強くな ること(クロムめっき)や, 高硬度を保ちながら摩擦低減を行 うこと(クロムめっき), 防食性を保ちながら耐熱性を有する こと(ニッケルー亜鉛合金)，プラスチック材に電磁波を閉じ 込めながら機械的強度を増すこと (ニッケルと銅の複層膜), などである。こうした膜特性とめっき条件パラメータの組み 合わせが複数で複雑になると，膨大な条件パラメー夕と特性 の因果関係を知ることが必要となり，もはや人では全容を把 握することは困難である。

そこで，人が把握しきれないめっきの膜特性と条件パラ メータの相関関係を提示することを目指して, 複数特性と条 件パラメータとの相関を蓄積し, 同時に性能を満足する条件 領域の設定と推奨条件提示を可能とするソフトウェアの開発 を行った。

図 2 に，複数の膜特性のグラフ領域の重なりと重なり度合 いを可視化できる推奨条件を提示するソフトウェアを示す ${ }^{8)}$ この図に示している事例データは, サージェント浴を用いた クロムめっきである。このクロムめっきでは, 実験で明らか にされているように，浴温度と電流密度を $\mathrm{X}$ 軸, $\mathrm{Y}$ 軸とす ると, Z 軸をビッカース硬さが $1000 \mathrm{HV}$ 以上になる領域と, 光沢がある領域, クラックが存在している領域との重なりが ある。

データの境界值を計算により自動的に決定する方法は数学 
が複雑で計算に膨大な時間がかかるため, 直線, 楕円，円の 計算式を有する平面図をグラフ上で切り取ってつなぎ合わせ ることで領域を順番に決定していく考え方を導入した。図 3 の下図に示したように，二つの放物線の内外のうちのどちら かを選択し, 平面を直線で分けることを 2 回繰り返すことで, 制限された領域を設定することができる。ここで得られた境 界はすべて数式に則った值を有しているので, 数学的手法で 境界領域を扱えることとなる。

図 2 では, クロムめっきの実験で得られた「クラックが存 在する」領域と「光沢が有る」領域を計算により決定した境 界領域を示してあり，一画面上で境界領域が重ね合わせて表 示されている。グラフ領域の画面表示を画面右上の透過率変 化バーを変化させることで, 複数のグラフ領域の重なりぐら いを確認することが可能となり, 複数の膜特性を同時に満足 する領域をデータの重なり具合を確認しながら相関関係を得 ることができる。また，重なった領域に含まれた膜特性を同 時に満たすめっき条件も，推奨とする条件パラメータとして 提示可能としている。このように, 数理モデルを組み込んで めっきの推奨条件領域を決定できるソフトウェア機能を作成 することで, 熟練者の有する高度知識技能をデジタル化し, ソフト上で実現することが可能になったといえる。

\section{3 機械学習を用いたサポートベクトル分類による マージン最大化と自動データ領域決定}

前項で述べたデー夕領域を決定する手法では，人間が数学 を駆使して領域設定をマニュアルで形成する式であった。こ の手法では，境界值を決める精度は優れたものになるが，領 域決定に多大な時間を有してしまい，また，次元数が 2 次元 から多次元化するとグラフとして表現ができなくなるため領 域の設定ができなくなる。このため, 多次元で境界領域を自 動決定することを目的で, 教師付き機械学習 (supervised learning)を用いる方法について試みた。

教師付き機械学習では, ある入力に対して, 期待する出力 があったものを正解デー夕として一緒に与え, 多量の入出力 ペアデータから入力と出力の相関をコンピュータ(機械)に学 習させている。学習モデル生成に扔いては, マージン最大化 という原理に基づいた「サポートベクトルマシン (support vector machine: SVM)」と呼ばれるパターン分類アルゴリズ ムを用いた。ここでは, 線形 2 クラスの分類の場合での SVM について簡単に説明する ${ }^{9)}$ 。

図 4 に示したように，標本とする訓練デー夕を $\left\{\left(x_{i}, y_{i}\right)\right\}_{i=1}^{n}$ と 2 次元データとした場合の線形分類器の関数は, 下記の通 りである。
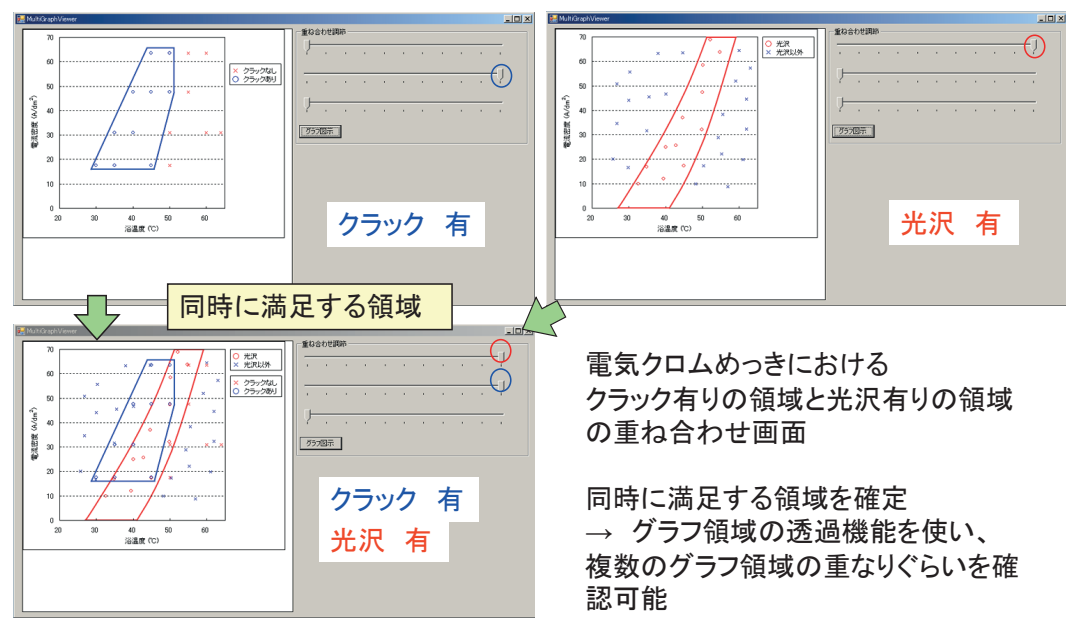

電気クロムめっきにおける

クラック有りの領域と光沢有りの領域 の重ね合わせ画面

同時に満足する領域を確定 $\rightarrow$ グラフ領域の透過機能を使い、 複数のグラフ領域の重なりぐらいを確 認可能

図 2 平面図切り貼り方式による境界值決定画面

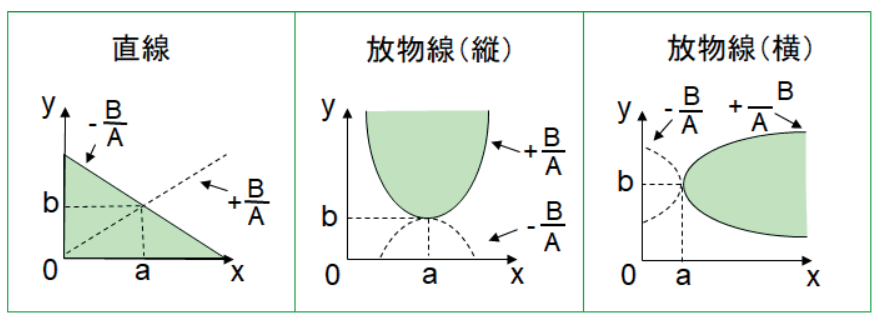

領域指定の例

(1)放物線1による領域指定

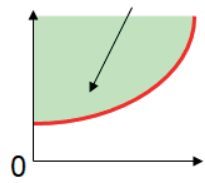

(2)放物線2による領域指定

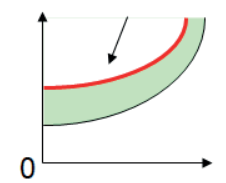

(3) 直線1による領域指定

(4)直線2による領域指定
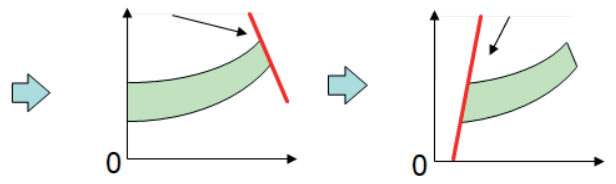

図 3 平面図切り貼り方式による境界值決定の考え方 


$$
f_{w}, \gamma(x)=w^{T} x+\gamma
$$

$w$ はクラス分離超平面の法線, $\gamma$ はクラス分離超平面の切片 を表す。ここで，各訓練データに対するマージン $\left(m_{i}\right)$

$$
m_{i}=f_{w, \gamma}\left(x_{i}\right) y_{i}
$$

がすべて正になるようにパラメータ $w$ と $\gamma$ を学習させること で, データすべてを正しく分離できる。めっきで取り扱うデー 夕は, 非線形であるため, SVM も非線形のものを使っている。 そこでは, 非線形関数を用いて多次元の特徵空間に写像し, その上で線形 SVM によって分類している。こうして得られ た特徵空間内での線形 SVM は，もとの空間では非線形の SVM となっており, 非線形領域での領域判定が可能となる。

\section{4 電気めっきのプロセスパラメータ決定への 機械学習の適用}

電気めっきのプロセスパラメータ決定への機械学習の適用 として, SVMを領域判定手法として実装した場合のソフト ウェアのフローを図 5 に示す。めっき膜で得られたデータの 「硬さ」データ, 「内部応力」デー夕, 「光沢度」デー夕のそ れぞれを分類器 (SVM)でモデル化し, それぞれのSVMの結 果を複数統合する, いわゆるアンサンブル学習により領域決 定を行った ${ }^{10)}$ 。

ここでは，「クロムめっきで膜応力ができるだけかからな い状態の光沢で硬い膜を得る」場合のめっき条件を探索する

$$
\begin{aligned}
& \text { 線形2クラス分類器 } \\
& f_{w, \gamma}(x)=w^{T} x+\gamma \\
& \text { マージン } \\
& \quad m_{i}=f_{w, \gamma}\left(x_{i}\right) y_{i}
\end{aligned}
$$

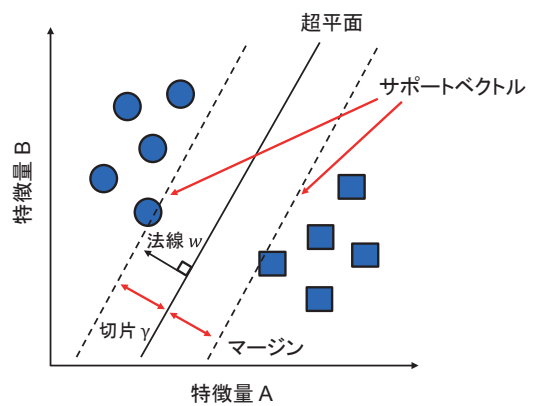

図 4 サポートベクトルマシンによるマージン最大化による境界領 域の決定
ことを例として取り上げ，クロムめっき膜の「ビッカース硬 さ」が HV1000 以上とそれ未満,「内部応力」が $200 \mathrm{MPa}$ 以 上とそれ未満, 「光沢性」の有無, という3つの膜特性の重 なる領域を決定することを試みた（図 6)。

図 7 はビッカース硬さ (HV)についての場合で, $\gamma を 0.0001$ から 0.1 まで変化させた場合の訓練モデルであり。電流密度, 浴温度に対して, めっきの「硬さ」が $1000 \mathrm{HV}$ 以上の領域の変化を示している。 $\gamma$ を大きくすると, 決定境界は不規則になり, 各データ(イン スタンス)の周囲で小さく円が形成される。一方, $\gamma$ 小さく すると, 各データ(インスタンス)の影響を受ける範囲が拡 がってつながり, 境界は滑らかになる。 $\gamma$ パラメータが最適 化されれば,「硬さ」データから機械学習により境界を自動 的に決定された領域範囲が表示される。同様に, クロムめっ きの「内部応力」と「光沢度」についても, ぞれぞれ SVM によってモデル化し, 境界領域を決定している。最後に, こ れらの 3 つの領域を重ね合わせることで, 3 つの膜特性をす べて満足するめっき条件が決定され，めっき推奨条件として 提示することが可能となる。この結果から,「ビッカース硬さ」 が $1000 \mathrm{HV}$ 以上で内部応力が $200 \mathrm{MPa}$ よりさく, 光沢を 有するめっきが得られる条件として, 浴温度が $40{ }^{\circ} \mathrm{C}$, 電流

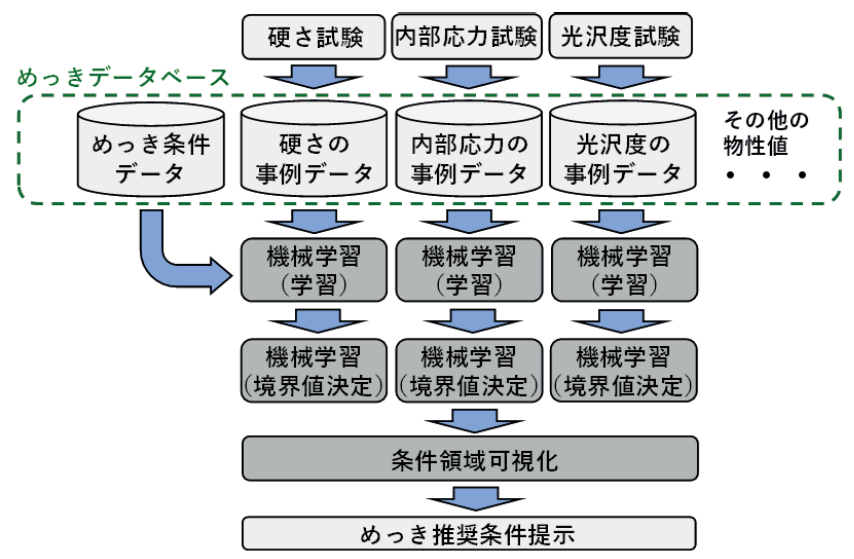

図 5 機械学習を用いた電気めっきのプロセスパラメータの決定 (めっき推奨条件提示ソフトウェア)のフロー
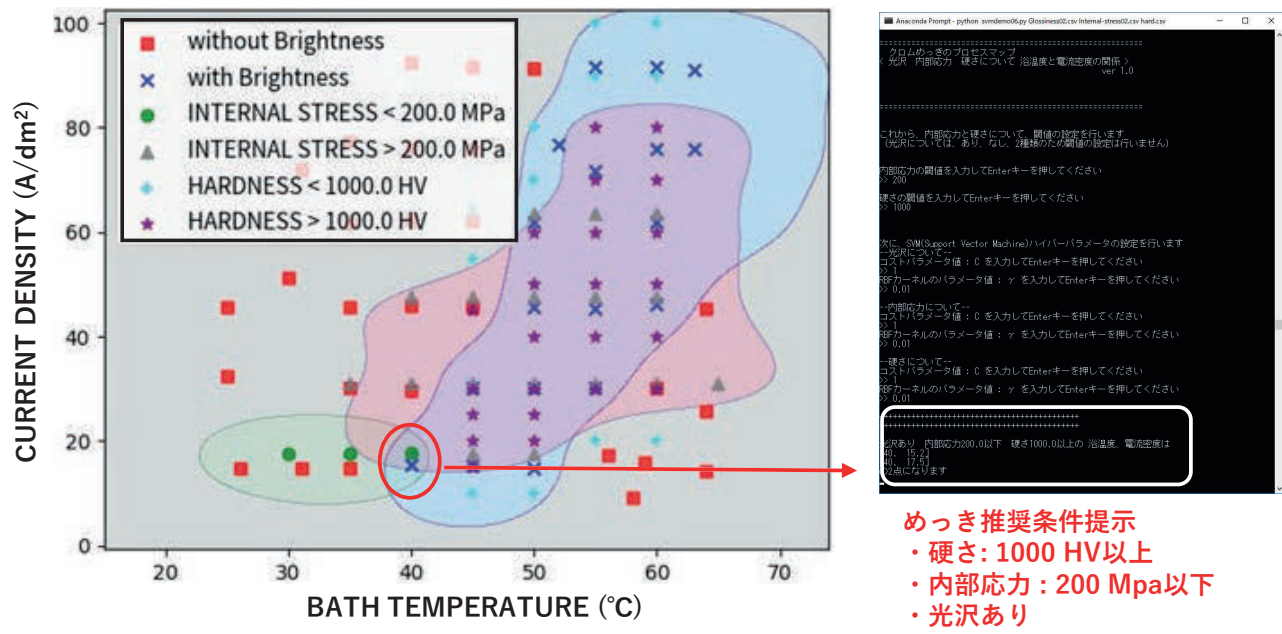

図 6 機械学習による判定(推奨条件領域の抽出) 

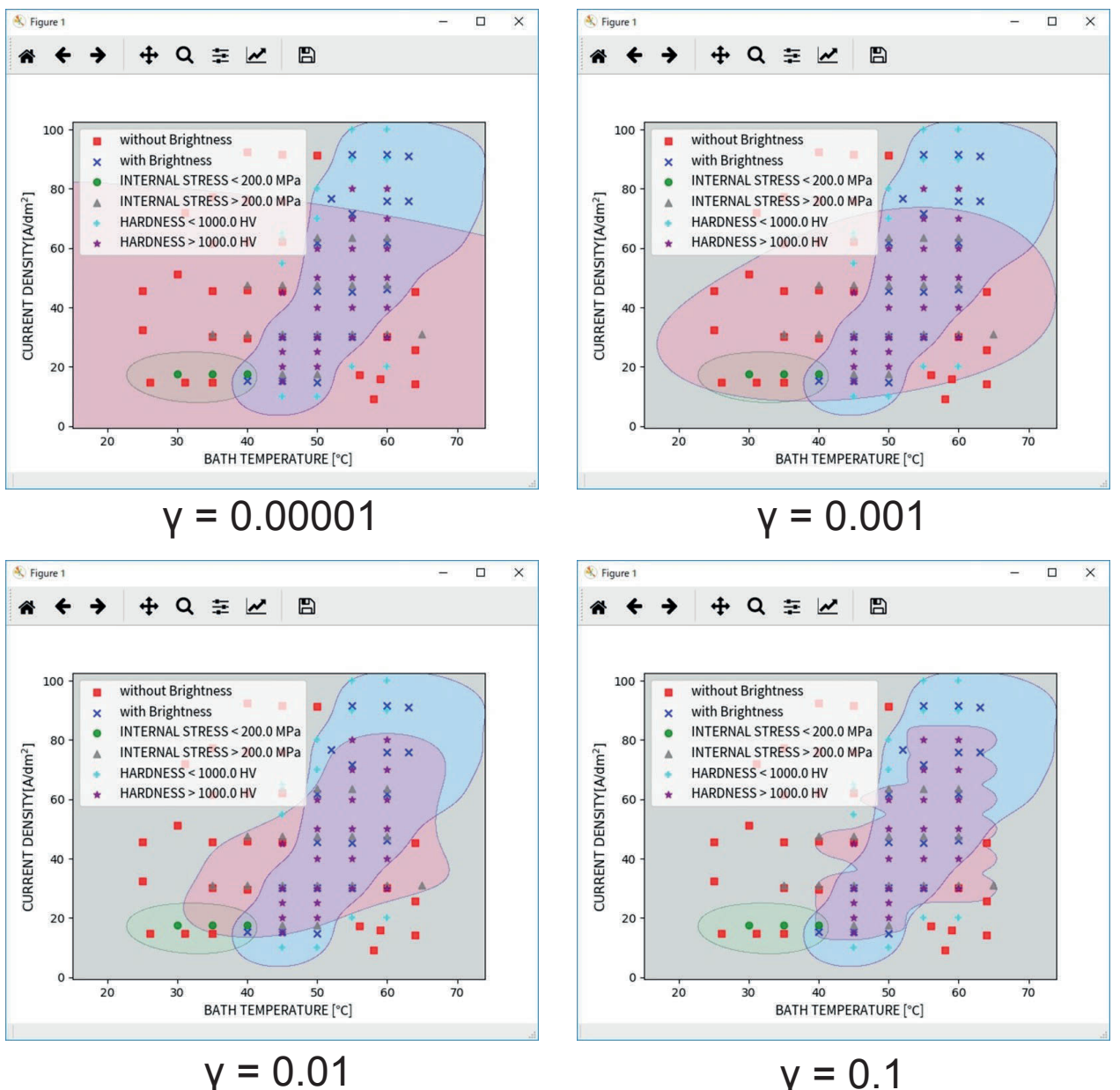

图 7 電流密度, 浴温度依存性デー夕における ムめっき硬さ領域の変化

密度は $20 \mathrm{~A} / \mathrm{dm}^{2}$ であることが機械学習を用いて得ることが できた。

\section{3. おわりに}

複数のめっき膜特性を満足するパラメータ決定を，教師付 き機械学習を用いて行った。筆者らは, 機械学習を部分的に 活用することは有効な場合があるのではないかと考えている。 複数の膜特性が求められる場合の条件パラメー夕の決定や, 膨大なめっき条件と膜特性との因果関係を知識として得る際 には機械学習は，とても有効な手段となりうる。ビックデー 夕を活用する時代，機械学習の可能性は広がっており，そう いう期待が持てる技術の一つであるといえる。

いつの日か, めっき熟練技能者の知識よりも機械の有する 知識のほうが多くなり，「適切なめっき条件の設定ができる」 ことも機械が考えて実行する時代がくるかもしれない。

(Received June 3, 2020)

\section{文献}

1 ）ものづくり懇談会;「ものづくり懇談会」提言 $(2000)$.
2 ) 中小企業庁編；中小企業の新しいものづくり一IT時代の中小製 造業の展望一( (財) 通商産業調査会, 2000).

3 ) 廣瀬伸吾 ; めっきデータベース・ウェブサイト, http://www. monozukuri.org/mono/db-dmrc/electroplating/index.html.

4) 廣瀬伸吾, 松田五明, 逢坂哲彌, 他 12 名; めっきデータベースの開 発と産学官連携を活用した今後のめっき企業のあり方, 表面技 術協会めっき部会12月例会テキスト,p. 1 (2004).

5 ) 廣瀬伸吾, 松田五明, 逢坂哲彌, 小島俊雄 ; 中小受託加工企業への アンケート調査でみるめっき業界の現状と将来像(第一報), 全 鍍連, 2月号, p. 13 (2004).

6 ) 廣瀬伸吾, 松田五明, 逢坂哲彌, 小島俊雄; 中小受託加工企業への アンケート調査でみるめっき業界の現状と将来像(第二報), 全 鍍連, 3 月号, p. 9 (2004).

7 ) (社) 雇用問題研究会編 ; 技能検定 学科試験問題解説集(めっき 技能者検定 1 級)。

8 ）廣瀬伸吾, 江塚幸敏, 森 和男, 大森 明; 第 128 回講演大会講演 要旨集, p.199 (表面技術協会, 2014).

9) 例えば,杉山 将;イラストで学ぶ機械学習 (講談社, 2013).

10）廣瀬伸吾, 江塚幸敏; 第139回講演大会講演要旨集, p.172（表面技 術協会, 2019). 